\title{
Marine Conservation Outcomes are More Likely when Fishers Participate as Citizen Scientists: Case Studies from the Mexican Mesoamerican Reef
}

\author{
Stuart Fulton*, Jacobo Caamal-Madrigal*, Alfonso Aguilar-Perera†, Luis Bourillón and \\ William D. Heyman $\$$
}

\begin{abstract}
Small-scale fishers on Caribbean coral reefs have exploited fish spawning aggregations (FSAs) for generations, but intense fishing has led to the loss of traditional aggregation sites. In many areas, the traditional ecological knowledge (TEK) of fishers has contributed greatly to the characterization of spawning aggregations and implementation of local conservation initiatives. TEK has identified more than 40 potential FSA sites along the coast of the Mexican Mesoamerican Reef. These sites have been characterised and scientifically validated, in some cases with traditional western science and in others, with a participatory citizen-science approach. The objective of this work is to compare the science and conservation outcomes at these FSA sites. We report that those FSA sites where scientific surveys were conducted without community participation remain unprotected. By contrast, the FSAs where local fishers were engaged in characterization and subsequent monitoring are now protected at the behest of the fishers themselves. Conservation initiatives to protect FSAs can be more effective through a combination of TEK, western science, and participatory citizen science involving local fishers.
\end{abstract}

Keywords: Spawning Aggregation; Traditional Ecological Knowledge; Fishers; Citizen Science

\begin{abstract}
Introduction
In the past decade, scientific studies involving the participation of members of the public (citizen science) have greatly increased in number (Conrad and Hindley 2011, Theobald et al. 2015). Bonney et al. (2014) define citizen science as scientific research and monitoring conducted by non-specialist individuals who are involved in collecting, categorizing, transcribing, or analysing scientific data. Citizen science encompasses a broad range of subjects and methods, covering topics ranging from observational data collected by keen hobbyists (e.g., bird surveys, Butcher and Niven 2007) to volunteer computing in which citizens do not actively participate, but lend resources, for example processing power (e.g., pulsar image analysis, Knispel et al. 2010). Objectives can answer specific scientific questions or focus on community-based monitoring (CBM), including population assessments, impact assessments, and adaptive management (Conrad and Hilchey 2011).
\end{abstract}

\footnotetext{
* Comunidad y Biodiversidad A.C., Guaymas, Sonora, MX + Departamento de Biología Marina, Universidad Autónoma de Yucatán, MX

* Independent Consultor, Puerto Morelos, Quintana Roo, MX

§ LGL Ecological Research Associates, Inc. Bryan, TX, US

Corresponding author: Stuart Fulton (sfulton@cobi.org.mx)
}

Technological advances driven by the smartphone revolution have allowed multitudes of people to participate in citizen science projects, particularly in terrestrial environments. Wider participation of citizens reporting sightings of key species has increased the size, geographical distribution, and analytical power of datasets used to address complex large-scale issues (e.g., Butcher and Niven 2007, McClellan et al. 2014, Theobald et al. 2015). Specific conservation outcomes are also targeted by CBM, whereby citizen scientists can provide and enhance the sustainability of long-term data collection and address specific management needs (Cigliano et al. 2015).

The marine environment poses challenges that may limit citizen involvement. Marine initiatives are proportionally underrepresented (Roy et al. 2012, Theobald et al. 2015), likely due to the difficulty and expense of project implementation. Limiting factors can include the cost of the equipment required, boat hire, safety and liability, or unclear access and resource rights (Roy et al. 2012, Cigliano et al. 2015). Due to these limitations, marine citizen science has predominated in high-income countries or popular SCUBA diving destinations (Pattengill-Semmens and Semmens 2003, Goffredo et al. 2004, Ward-Paige et al. 2010). Until recently, information transfer from stakeholders to scientists in developing countries relied on traditional ecological knowledge (TEK) rather than active stakeholder participation in data collection (see Thornton 
and Maciejewski-Scheer 2012 for review). However, new initiatives (e.g., ABALOBI 2017) are using smartphone technology to improve fisheries management in datapoor scenarios, address traceability issues, and promote stewardship.

Fish spawning aggregations (FSAs) are large gatherings of fish that come together for the purpose of reproduction (Sadovy de Mitcheson and Colin 2012). On coral reefs, FSAs occur at specific locations and times of year (Heyman and Kjerfve 2008, Gleason et al. 2011, Colin 2012, Kobara et al. 2013), and in most cases, local fishers were first to discover such sites. FSA sites can be multispecific with different fish species using the same area at different times of year (e.g., Heyman and Kjerfve 2008). In the Caribbean Sea, commercially important fish, such as groupers (Epinephelidae) and snappers (Lutjanidae), form aggregations to spawn (Sadovy de Mitcheson et al. 2008). Fishers can harvest large numbers of fish with minimal effort at FSA sites during spawning seasons. In many cases, fishing has led to local extirpation of an FSA (Sadovy and Domeier 2005, Sadovy de Mitcheson et al. 2008, Sadovy de Mitcheson et al. 2012).

Worldwide, conventional fisheries management has relied on traditional tools such as size and catch limits, gear restrictions, and closed seasons. In many developing countries, however, such tools are difficult to implement given limited resources for effective enforcement. Small, completely protected marine reserves have been cited as effective tools for protecting FSA sites (Erisman et al. 2015). However, knowledge gaps exist in the understanding of the location of FSAs (Kobara et al. 2013) and, as such, managers can be reluctant to implement conservation measures. A review of the objectives for 55 Caribbean multiuse protected areas found that only four considered FSA management in their design (Appeldoorn and Lindeman 2003). In one extreme example, a Black Grouper FSA was discovered just beyond the boundary of a protected area (Eklund et al. 2000) and therefore offered no protection.

In his thoughtful and somewhat provocative paper "The case for data-less management," Johannes (1998) explained how conventional biological training has created conditions in which scientists can be reluctant to commit to conservation management decisions without a quantitative description of the resources at hand. However, due to the data gaps still present in FSA science, and the continued population declines in many fish species that aggregate to spawn (Sala et al. 2001, Sadovy and Domeier 2005, Sadovy de Mitcheson et al. 2012), datapoor management approaches are now being considered. Data-poor management, however, does not necessarily mean data-free (as proposed by Johannes 1998), and advocates of the approach draw on all available data to propose optimal management solutions that account for both the existing scientific information and the TEK of the local fishers (Heyman 2011).

In this study, we define traditional western science (WS) as research conducted by trained scientists (from academia or NGOs) that is objective, generally quantitative, analytical, and reductionist, and often results in publications and, in some cases, policy and management recommendations. In contrast, participatory citizen science $(C S)$ uses a western science approach but, in addition, involves the continued participation of fishers in the scientific aspects of research, analysis, and in making and implementing policy recommendations.

Both traditional western science and participatory citizen science approaches have been used to verify and characterize FSA sites along the Mexican portion of the Mesoamerican Reef (MAR), but no comparisons between these techniques and their respective conservation outcomes have been previously made. All potential FSA sites were originally identified via TEK. Of these, some were characterized using solely traditional western science and conducted by scientists from either academia or from NGOs. Others were characterized using a participatory citizen science approach involving local fishers supported by researchers and NGOs. The objective of this paper is to compare the scientific and conservation outcomes achieved by these differing approaches.

\section{Methods \\ Study Area}

The MAR extends over $1,000 \mathrm{~km}$ from the tip of the Yucatan Peninsula in Mexico to the Bay Islands of Honduras. The study area covers a $230 \mathrm{~km}$ section from the northern edge of the Sian Ka'an Biosphere Reserve to Xcalak on the Belize border (Figure 1). This central and southern section of the Mexican State of Quintana Roo lacks the mass tourism destinations found in the north of the peninsula and is home to three Protected Areas (PAs): The Sian Ka'an Biosphere Reserve complex (SKBR), Banco Chinchorro Biosphere Reserve (BCBR), and Xcalak Reef National Park (XRNP). All PAs are zoned as multiuse; fishing is permitted in most of the area but with restrictions, particularly on gear type.

Fishing activities occur throughout the study area, with seven fishing cooperatives totalling approximately 209 fishers principally catching lobster and small amounts of finfish. An eighth cooperative (eight fishers) exclusively targets finfish. Approximately 15 additional individual permit holders and an unknown number of unregulated fishers operate in the area.

\section{Review of FSA Scientific Knowledge in the Mexican MAR}

TEK provides the foundation for all FSA work in the Mexican MAR. The first study to document several FSAs was completed by Aguilar-Perera (1994), while Sosa-Cordero et al. (2002) published the most comprehensive study to date. In both cases, the principal data source was interviews and surveys with veteran fishers, completed by documented sources and grey literature. Sosa-Cordero et al. (2002) identified 39 potential FSA sites for diverse species. Local NGOs replicated the studies on a smaller scale during the mid-2000s (Franquesa-Rinos and Loreto-Viruel 2006, ASK and COBI 2010). The NGOs worked closely with the fishers to reconfirm and prioritise the Sosa-Cordero 


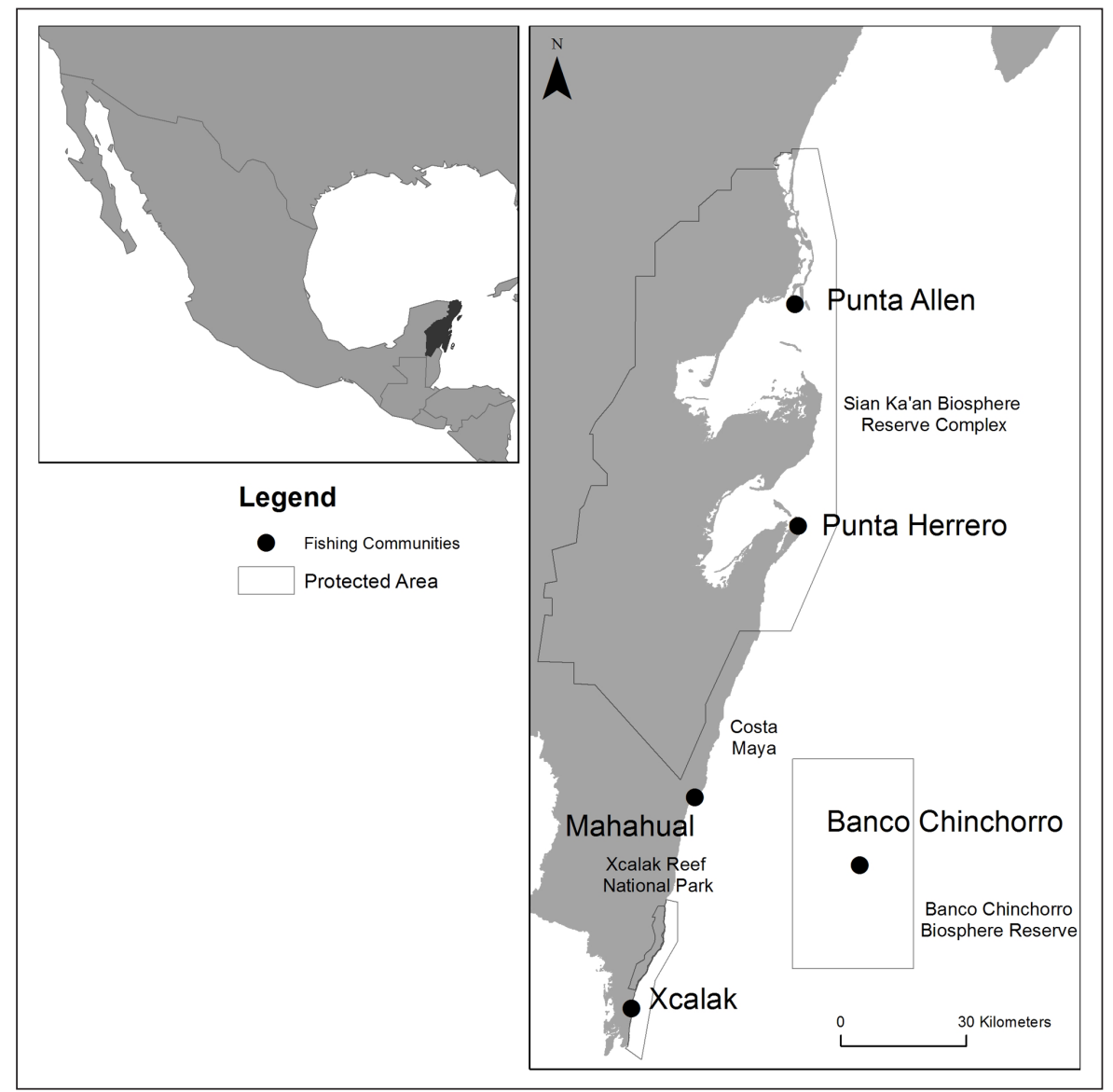

Figure 1: Map of the study area.

et al. (2002) data. The 39 original FSAs were revised down to 29 , as some sites were clustered and likely represented the same FSA (Fulton et al. 2016).

We searched published literature available in online scientific databases and in grey literature to find references to fieldwork conducted in the region. Three groups were identified: Academics using western science without fisher involvement (western science "WS"), NGOs using western science without local fishers ("WS" ${ }^{* \prime}$ ), and mixed groups of academics, NGOs, and local fishers (citizen science " $C S^{\prime \prime}$ ). For each study, we identified the methodology used, if bathymetric maps were created, if FSAs were validated and by what method, and the level of involvement of local fishers.

\section{Results}

\section{Methodologies for FSA Site Characterization}

The fieldwork methodologies used by each group (WS, WS*, and CS), identified in the literature review, were similar (Table 1). Each group mapped the spawning sites (sketch maps and/or bathymetry) and conducted underwater visual censuses (UVC) to document spawning behaviour (WS: Aguilar-Perera 1994, Medina-Quej et al. 2004; WS*: ASK and COBI 2010; CS: Franquesa-Rinos and Loreto-Viruel 2006, ASK and COBI 2010, Fulton et al. 2016). At one site, the group did not conduct in-water verification, relying instead on fishery-dependent data to identify the FSA (WS: Castro-Pérez et al. 2011).

\section{Characterization of FSA sites using participatory citizen science (CS)}

The San Juan FSA (Figure 2; Table 1), in the northern part of the SKBR, was characterized by a local NGO and trained fishers from the community in 2005 (Franquesa-Rinos and Loreto-Viruel 2006) and 2008 (ASK and COBI 2010). The site was mapped and biologically characterized through underwater visual census (UVC). Divers reported purported spawning aggregations of 200 Nassau Grouper and 100 Black Grouper (Mycteroperca bonaci), from changes in colouration and behaviour, located on the shelf-edge in $35 \mathrm{~m}$ of water. Fishers from the same community returned in 2015 with other scientists and reported 50 Nassau Grouper and 30 Black Grouper (Fulton et al. 2016). Due to the observed decline in fish abundance in these aggregations, recommendations were made to the community to close the site to fishing.

The Punta Allen FSA, also in northern SKBR, followed a similar process to San Juan. NGO and community characterizations in 2005, 2008, and 2015 (Franquesa-Rinos and Loreto-Viruel 2006, ASK and COBI 2010, Fulton et al. 2016) reported 1,000 Nassau Grouper located at $35 \mathrm{~m}$ depth on a large spur and groove coral reef. The fishers reported that the site has rarely been fished in the last 10 years, but with the observed abundance of this endangered species in a spawning aggregation, it was considered worthy of legal protection. 
Table 1: Current status of verified fish spawning aggregation sites in central and southern Quintana Roo.

\begin{tabular}{|c|c|c|c|c|c|c|c|c|}
\hline \multirow{2}{*}{$\begin{array}{l}\text { Fish } \\
\text { Spawning } \\
\text { Aggrega- } \\
\text { tion Site }\end{array}$} & \multirow{2}{*}{$\begin{array}{l}\text { Source of Tradi- } \\
\text { tional Ecological } \\
\text { Knowledge (TEK) }\end{array}$} & \multicolumn{4}{|c|}{$\begin{array}{c}\text { Characterization Team and } \\
\text { Process }\end{array}$} & \multirow{2}{*}{$\begin{array}{l}\text { Species documented } \\
\text { (reference for } \\
\text { visual } \\
\text { verification) }\end{array}$} & \multicolumn{2}{|c|}{$\begin{array}{l}\text { Conservation } \\
\text { Outcome }\end{array}$} \\
\hline & & $\begin{array}{l}\text { Initial } \\
\text { field } \\
\text { investi- } \\
\text { gation }\end{array}$ & $\begin{array}{l}\text { Site } \\
\text { Map }\end{array}$ & UVC & $\begin{array}{l}\text { Docu- } \\
\text { mented } \\
\text { Spawning }\end{array}$ & & $\begin{array}{l}\text { Included } \\
\text { within } \\
\text { Federal } \\
\text { MPA } \\
\text { (date) }\end{array}$ & $\begin{array}{l}\text { FSA } \\
\text { protected } \\
\text { within } \\
\text { NTZ } \\
\text { (date) }\end{array}$ \\
\hline San Juan & $\begin{array}{l}\text { Sosa-Cordero et al. } \\
2002\end{array}$ & CS & CS & CS & CS & $\begin{array}{l}\text { Epinephelus striatus } \\
\text { Mycteroperca bonaci } \\
\text { (Franquesa-Rinos and } \\
\text { Loreto-Viruel 2006, } \\
\text { Fulton et al. 2016) }\end{array}$ & Y (1986) & Y (2016) \\
\hline Punta Allen & $\begin{array}{l}\text { Sosa-Cordero et al. } \\
2002\end{array}$ & CS & CS & CS & CS & $\begin{array}{l}\text { Epinephelus striatus } \\
\text { (Franquesa-Rinos and } \\
\text { Loreto-Viruel 2006, } \\
\text { Fulton et al. 2016) }\end{array}$ & Y (1986) & Y (2016) \\
\hline $\begin{array}{l}\text { Punta } \\
\text { Herrero }\end{array}$ & $\begin{array}{l}\text { Sosa-Cordero et al. } \\
2002\end{array}$ & CS & CS & CS & CS & $\begin{array}{l}\text { Epinephelus striatus } \\
\text { Mycteroperca venenosa } \\
\text { Lutjanus analis } \\
\text { Lutjanus jocu } \\
\text { (Fulton et al. 2016) }\end{array}$ & Y (1986) & Y (2013) \\
\hline Mahahual & $\begin{array}{l}\text { Aguilar-Perera 1994, } \\
\text { Sosa-Cordero et al. } \\
2002\end{array}$ & WS & WS & WS & WS & $\begin{array}{l}\text { Epinephelus striatus } \\
\text { (Aguilar-Perera 1994) }\end{array}$ & $\mathrm{N}$ & $\mathrm{N}$ \\
\hline Maya Ha & $\begin{array}{l}\text { Aguilar-Perera 1994, } \\
\text { Sosa-Cordero et al. } \\
2002\end{array}$ & WS* & WS* & WS* & WS* & $\begin{array}{l}\text { Mycteroperca bonaci } \\
\text { Lutjanus cyanopterus } \\
\text { (ASK and COBI 2010, } \\
\text { Fulton et al. 2016) }\end{array}$ & $\mathrm{N}$ & $\mathrm{N}$ \\
\hline Xcalak & $\begin{array}{l}\text { Sosa-Cordero et al. } \\
\text { 2002, Medina-Quej et } \\
\text { al. } 2004\end{array}$ & WS & WS & WS & WS & $\begin{array}{l}\text { Epinephelus striatus } \\
\text { Mycteroperca tigris } \\
\text { Mycteroperca bonaci } \\
\text { (Medina-Quej et al. } \\
\text { 2004) }\end{array}$ & Y (2000) & $\mathrm{N}$ \\
\hline $\begin{array}{l}\text { Banco } \\
\text { Chinchorro }\end{array}$ & $\begin{array}{l}\text { Aguilar-Perera 1994, } \\
\text { Sosa-Cordero et al. } \\
2002, \\
\text { Castro-Pérez et al. } \\
2011\end{array}$ & WS & CS & $\mathrm{CS}$ & $\mathrm{CS}$ & $\begin{array}{l}\text { Lutjanus analis } \\
\text { (Heyman et al. 2014) }\end{array}$ & Y (1996) & $\mathrm{N}$ \\
\hline
\end{tabular}

CS: Citizen Science (participatory science involving local fishers, NGOs, and academics). WS: Academics using western science without fisher involvement. WS*: NGO using western science without local fishers.

The Punta Herrero site, located in the southern part of the SKBR, was characterized through CS with fishers from the cooperative "José María Azcorra" beginning in 2008. A small FSA of Nassau Grouper was reported at a depth of 30 $\mathrm{m}$, on a small drop-off in an area of strong currents (ASK and COBI 2010). Site protection was proposed in 2010 to protect the Nassau Grouper FSA. Between 2013 and 2015, fishers and scientists mapped and further characterized the site with UVC and reported FSAs of 150 Nassau Grouper, 30 Yellowfin Grouper (Mycteroperca venenosa), 1,500 Mutton Snapper (Lutjanus analis), and 800 Dog Snapper (Lutjanus jocu) (Fulton et al. 2016).

\section{Characterization of FSA sites using western science (WS/WS*)}

Fishers had been aware of a Nassau Grouper FSA at Mahahual for over 100 years (Aguilar-Perera 1994) (Figure 2). The site was initially described and mapped between 1988 and 1990 by WS (Aguilar-Perera 1994), and UVC were used to document 1,000 Nassau Grouper on a shallow reef between 10 and $16 \mathrm{~m}$ depth. Aguilar-Perera $(1994,2013)$ was the first to make management recommendations for FSA sites in the Mexican MAR, with the particular aim of preventing the disappearance of the Nassau Grouper FSA in Mahahual. These recommendations included banning spearguns, implementing a closed season, and improving surveillance and enforcement. The study also recommended working with fishers to highlight the ecological importance of the FSA in Mahahual and providing economic alternatives to reduce fishing pressure on the aggregation.

The Maya-Ha Black Grouper FSA site, located in the Costa Maya region, was originally verified by a local NGO in 2009 without local fisher participation (ASK and COBI 2010) (Figure 2; Table 1). Site-specific management recommendations were not made. The site was revisited in 


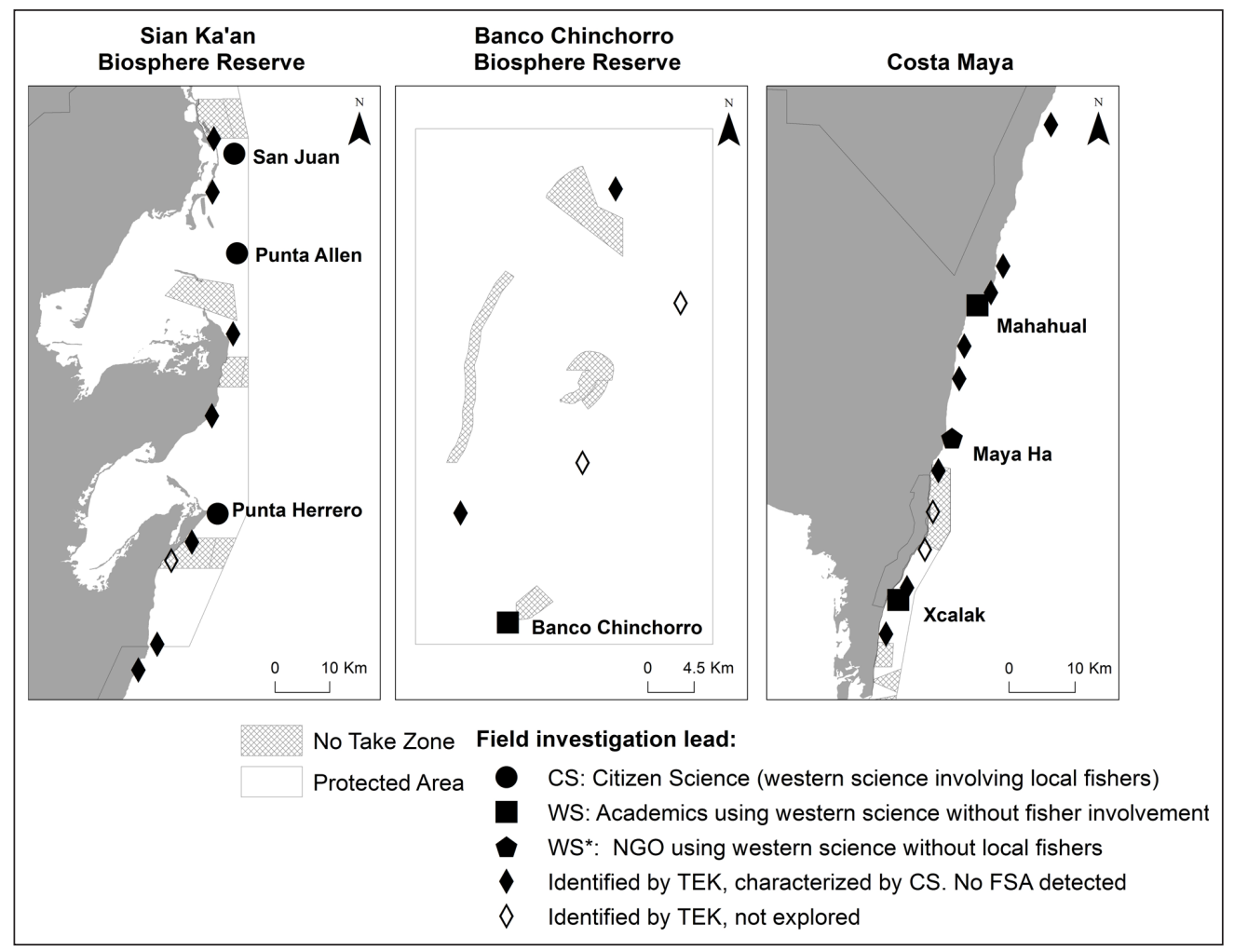

Figure 2: Location of documented FSA in the Mexican MAR.

2016 with fishers who were not local to the area. The team produced a bathymetric map of the site and used UVC to document aggregations of 30 Black Grouper and 45 Cubera Snapper (Fulton et al. 2016).

In Xcalak, commercial catch of Nassau Grouper was registered and UVC conducted by WS on the FSA between 2001 and 2002 (Medina-Quej et al. 2004). The FSA of 3,000 groupers, the largest reported in the literature in Mexico, forms on a spur and groove reef at approximately $35 \mathrm{~m}$ depth (Figure 2; Table 1). The researchers reported that fishing pressure was low, and recommended that the management plan for the PA take the FSA site into consideration.

Researchers (WS) published the first record of a Mutton Snapper FSA in Banco Chinchorro (Castro-Pérez et al. 2011). Coordinates were provided for the FSA based on catch data provided by the fishers, however, the FSA was not visually verified. The authors mentioned that fishing impact in Banco Chinchorro is low to moderate due to the restrictions of the biosphere reserve, and recommended seasonal closures for the FSA. A community CS monitoring team was established in 2012 in collaboration with NGOs and the reserve authorities. The team visually confirmed an aggregation of 3,000 Mutton Snapper at a location $3 \mathrm{~km}$ from the shallow banks where the aggregation was first reported, at a depth of over $40 \mathrm{~m}$ on the shelf edge (Figure 2; Table 1; Heyman et al. 2014).

\section{Protection Status}

Mexican legislation includes several instruments that can be used to protect critical habitat, ecosystems, or species. The two instruments relevant for this article and implemented in the Mexican MAR are multiple-use protected areas managed by the National Commission of Natural
Protected Areas (CONANP in Spanish) and no-take zone (NTZ) Fish Refuges managed by the National Commission of Aquaculture and Fisheries (CONAPESCA). PAs include different zoning schemes that can limit and prohibit fishing, such as core zones. Fish Refuges are a relatively new instrument, created under the Sustainable Fisheries and Aquaculture Law in 2007 (Secretaria de Gobernación 2007) and first implemented in 2012.

\section{Protection status of FSA sites characterized using participatory citizen science (CS)}

The three northernmost FSA sites (San Juan, Punta Allen, and Punta Herrero) are located in the SKBR. This Federal PA was established in 1986 (Secretaria de Gobernación 1986) and contains a multiple-use zoning scheme of which $100 \mathrm{~km}^{2}$ are closed to fishing, except for subsistence and lobster fishing. The management plan for the PA states that grouper and snapper FSA are found inside the PA no-take zones (Secretaría de Medio Ambiente y Recursos Naturales 2014), however, the three confirmed FSA were verified 20 years after the PA was created, and efforts to locate FSA in the PA no-take zones have not been successful. The characterized San Juan FSA described in the study is located $2.8 \mathrm{~km}$ from one such no-take zone, the Punta Allen FSA 6 km distant, and the Punta Herrero FSA $4.4 \mathrm{~km}$ away (Figure 2). Effort control also exists, as spearguns and nets are prohibited throughout the PA.

In 2013, the Punta Herrero FSA was protected under the fisheries legislation at the petition of the local fishers with help from local NGOs (Secretaria de Gobernación 2013). The Punta Herrero Fish Refuge covers $4.3 \mathrm{~km}^{2}$ and represents the first time that this legislation was used to protect a FSA in Mexico. In 2016, the San Juan and Punta Allen sites were also protected at the petition of the 
fishing community using the same legislation (Secretaria de Gobernación 2016), with a $16.3 \mathrm{~km}^{2}$ and $15.8 \mathrm{~km}^{2}$ Fish Refuge respectively.

\section{Protection of FSA sites characterized using western science (WS/WS*)}

The Mahahual and Maya-Ha FSAs are not found within a PA. The Mahahual FSA was reported as extinct by 1996 (Aguilar-Perera 2006, 2013). Considerable WS research was conducted on the site (Aguilar-Perera 1994, 2006, 2013, Aguilar-Perera and Aguilar-Davila 1996), and it remains the best-described FSA to date in Mexico despite no continuous monitoring program being implemented. Management recommendations were implemented as the size of the FSA diminished, with CONAPESCA enacting a ban on spearguns and gill nets in 2006 and a complete ban on fishing during spawning season in 2007 (Aguilar-Perera 2013). Lack of enforcement saw these actions abandoned the following year. The Maya-Ha FSA is believed to be fished from fishers from the town of Mahahual, but no data exist on effort or landings, and no efforts have been made to manage or protect the FSA.

In Xcalak, the FSA is located within the XRNP, a PA created in 2000 (CONANP 2004). The PA contains a specific "Special Production Zone - Grouper" (Zona de Aprovechamiento Especial Mero), in which the management plan recognises the presence of a FSA (although commercial fishing is permitted). This site, known as Punta Gavilan, was identified from TEK over 20 years ago (Aguilar-Perera 1994), but no data have since been published to confirm the presence of spawning fish. The visually verified aggregation (Medina-Quej et al. 2004) lies 1.9 $\mathrm{km}$ to the south of the Special Production Zone. The site continues to be monitored by a local research institute (WS).

The Banco Chinchorro FSA is found within the BCBR, a Federal PA that includes $68 \mathrm{~km}^{2}$ of no-take zones. Effort controls also exist; spearguns are prohibited by the management plan during fish reproduction seasons (SEMARNAP 2000). Catch data is collected during the spawning season by the reserve authorities. The recently documented Mutton Snapper FSA is located approximately $800 \mathrm{~m}$ beyond the edge of the nearest NTZ (Table 1, Figure 2).

\section{Discussion}

Conservation Outcomes of WS, WS*, and CS-led FSA Studies

This study compared the outcomes from case studies using western science $(W S)$ to those using a participatory citizen science $(C S)$ approach for the characterization and conservation of fish spawning aggregation sites in the Mexican MAR. All potential spawning sites were first identified with fishers' traditional ecological knowledge. Our results show that the four FSA sites characterized by researchers using WS without community involvement (Mahahual, Maya $\mathrm{Ha}$, Xcalak, and Banco Chinchorro) remain open to fishing. In each of these cases, WS provided site characterizations and clear management recommendations (Aguilar-Perera 1994, Medina-Quej et al. 2004, ASK and COBI 2010,
Castro-Pérez et al. 2011). None of the recommendations have been implemented effectively, however. One site serves as an extreme example: The FSA site at Mahahual was fished to extinction (Aguilar-Perera 2013). By contrast, the three sites where the fishing community took part in the FSA characterization, monitoring, and evaluation (San Juan, Punta Allen, Punta Herrero) are now protected within no-take zones after fishers petitioned the government for their establishment (Secretaria de Gobernación 2013, 2016; Table 1).

The successful implementation of fisheries conservation measures presented in this paper occurred when western science, citizen science, and traditional ecological knowledge were effectively combined. The protection of three FSAs documented herein was made possible through community level collaborations between researchers, civil society, government, and fishers. This citizen science programme resulted in the training of 38 local fishers as SCUBA divers, who characterized the FSA sites near their communities and generated the data required for their protection using the existing legal framework. The sites were protected by the National Commission of Aquaculture and Fisheries (CONAPESCA) under the fisheries legislation, a flexible and dynamic management tool. These areas were, and continue to be, considered both data-poor and with low levels of enforcement, although fishers operate community surveillance programmes with some governmental support.

In contrast, at the four FSAs where a CS component was not included (Table 1), information and management recommendations were made (Aguilar-Perera 1994, 2006, Medina-Quej et al. 2004, Castro-Pérez et al. 2011), but the recommendations were not implemented with long-term success. For example, CONAPESCA temporarily implemented some of the recommendations made for the Mahahual FSA, however, the regulations were enforced only briefly, and fish stopped aggregating at the site shortly after (Aguilar-Perera 2006, 2013). Incidentally, this FSA had been fished at low levels for decades, but a race to fish in recent years, driven by a growing population and tourism developments, and including the use of new fishing gear, harpoons and, reportedly, dynamite (Aguilar-Perera 1994) quickly led to its extinction.

\section{Driving factors for FSA protection}

Social and economic factors need to be recognised as important contributions to the enabling environment for the establishment of the three NTZs in this study. The cooperatives that created the NTZs form part of the Kanan Kay Alliance (www.alianzakanankay.org), a voluntary, multisectoral collaborative network formed by more than 40 organisations including fishing cooperatives, government agencies, NGOs, research centres, and philanthropic foundations with the aim of creating NTZs and encouraging sustainable fishing practices. The Alliance creates dialogue spaces in which conservation initiatives are coordinated. Fishers are active participants and thus feel included and more willing to implement the recommendations (Moreno et al. 2016). Before the NTZs were implemented, surveys were conducted to evaluate the 
perception of fishers towards fisheries, NTZs, and the community-based process (Velez et al. 2014). Additionally, socioeconomic studies were conducted on the fishing cooperatives (Bobadilla 2014) with the results allowing focussed capacity-building for each cooperative's needs, including strengthening their internal structure and leadership to allow them to invest in conservation and sustainable fishing.

It is also possible that the lucrative lobster fishery in the SKBR has reduced pressure on the finfish fishery in the past decades, making FSA protection more amenable within the traditional fishing grounds. However, the extent to which fishers are willing to protect FSAs varies in each community. The cooperative in Punta Allen now lands very few fish (10-year average of 3.7 tonnes per year), and closing a FSA site to fishing likely had little effect on production. However, the cooperative in Punta Herrero continues to exploit the finfish fishery (10-year average of 49.5 tonnes per year) to complement their income from lobster, and the creation of the marine reserves has required a stronger commitment by the community. At the same time, regional stocks of transient spawning fish such as groupers continue to decline (Secretaria de Gobernación 2014).

In contrast, Mahahual is the only coastal community in the Mexican MAR without a registered fishing cooperative based in the village, reducing the possibility of collaborative work with the fishing community. Mahahual residents also have a pessimistic view of the future; $68 \%$ of residents expect fewer fish in the future and only $12 \%$ believe that regulations can change the situation (Cinner and Pollnac 2004). The fact that several conservation initiatives have failed to be successfully implemented in Mahahual (e.g., Amigos de Sian Ka'an 2003) reflects that the scope and target of such projects did not successfully address underlying conditions, unite the community, nor seek to strengthen socioeconomic factors that could promote successful achievement of conservation goals (Cinner and Pollnac 2004).

\section{Promoting an enabling environment for FSA site protection}

Heavy fishing pressure on aggregations is not sustainable (Sadovy and Domier 2005). In all cases, a precautionary approach is recommended (Erisman et al. 2015, Sadovy de Mitcheson 2016). WS is often the first to raise conservation concerns and to make management recommendations; however, this raises the question of who is responsible for implementing the conservation measures. Should researchers always make management recommendations? And how can we improve the implementation of such recommendations? The "knowing-doing gap" that has been identified in conservation science (Knight et al. 2008) is relevant to this discussion. Whilst research faculty tenure and promotion at most academic institutions are generally dependent on excellence in research, teaching, and service, implementation of research recommendations, including conservation, is generally not linked with job security and advancement. Though some institutions are increasingly valuing service learning and societal contributions in the tenure and promotion process (June 2013), there have traditionally been disincentives within academia for cross-disciplinary research and its applications in conservation (Arlettaz et al. 2010, Gibbons et al. 2008; Knight et al. 2008). This is definitely the case in Mexico, where the National Council of Science and Technology (CONACYT) can make substantial contributions to top researchers' incomes based on research productivity, defined in terms of publications and grants (Altbach 2015). Critics of the reward system also argue that it discourages collaboration and more heavily rewards papers published in English (Altbach 2015). These incentives contribute to the implementation gap, as the most important research may not be immediately available to local practitioners, or in a language they understand, and academics are not rewarded by their employers for participating in the implementation of their recommendations.

However, the burden of implementing management recommendations must fall on all sectors. Collaborative efforts between researchers (who provide the technical expertise) and NGOs (who often provide long-term financial support and continuous presence in fishing communities, particularly in developing countries) are becoming commonplace (Da Fonseca 2003, Hamilton et al. 2011). In Mexico, monetary (Pérez-Cervantes et al. 2017) and political constraints (Hernandez and Kempton 2003) often limit government capacity to incorporate recommendations into adaptive management schemes. Delayed action can be costly (Mangin et al. 2018), and all sectors should work alongside the fishing communities to incorporate TEK, find socially acceptable solutions, and promote community buy-in.

This study also revealed the need for TEK to be accompanied by effective science to guide conservation and management (Hamilton et al. 2012). In those sites in which federal protected area zoning (e.g., SKBR, BCBR, XRNP) occurred before adequate science had been completed (either WS or CS), FSA sites that were described by TEK alone were not successfully protected. FSAs were subsequently found close to, but not in, NTZs (Table 1). Field verification of FSAs has shown that TEK is not always accurate, and anecdotal information needs to be validated through field observations. In the Mexican MAR, it appears that TEK data were collected before the PAs were zoned, but field verifications were not completed to adequately geolocate the FSAs. For example, the management plan for the SKBR (Secretaría de Medio Ambiente y Recursos Naturales 2014) recognises the importance of protecting FSA sites and states that the zoning protects FSAs of grouper and snapper. Unfortunately, despite considerable effort by the CS teams, to date it has not been possible to visually verify these sites, and the only confirmed sites are located just outside the NTZs. The management plan acknowledges that information is lacking regarding FSAs and that further studies are required to locate the sites with precision, however, rezoning federal protected areas can be a long process. The flexibility offered by the Fish Refuge legal framework allows for bottom-up approaches whereby fishers can directly petition the federal fishing authorities to enact conservation measures. The law 
was first used in 2012, and fishers feel a great sense of ownership for the NTZs that they proposed and that were ultimately created. Compromises, however, must also be made. The three NTZs have each been established for a minimum period of five years, with options for renewal, modification, or removal at the end of the period. This time is too short for recovery of grouper biomass to preexploitation levels, with marine reserve design principals recommending permanent reserves (Green et al. 2014) to maximise benefits. However, this was the first time this type of protection was applied to FSA in Mexico, and fishers must become familiar with the framework.

Though worldwide FSA protection within NTZs is woefully inadequate (Russell et al. 2014), there are a growing number of successful examples where FSAs have been placed within NTZs with varying methods and levels of local support. For example, a Florida fisher suggested Riley's Hump in the Florida Keys for NTZ status because it served as a multi-species FSA (Locascio and Burton 2016). Characterization was conducted largely by scientists, and the initial local reaction to the closure was hostile. Local residents showed growing support after seeing that the protection has effectively fostered fish returning to spawn (DeMaria pers. comm., Burton et al. 2005). FSA conservation projects in the Solomon Islands also have illustrated the value of combining TEK with citizen science (Hamilton et al. 2012). The community reported declining catches, but researchers and NGOs stepped in to raise awareness and involve the community in monitoring their resources. This led to the creation of a community-based NTZ at the site. In Belize, eleven multi-species FSA sites were closed in 2003 with full support from fishers, following three years of extensive characterization work conducted in partnership between researchers, national and international NGOs, the Government of Belize, and fishers as citizen scientists (Heyman 2011).

By contrast, many examples exist where FSA conservation efforts have been hampered by insufficient community involvement in research. In the Cayman Islands, scientific characterization efforts from the national government's Department of Environment, with support from the international NGO REEF, led to the protection of an important Nassau Grouper FSA, which has since shown impressive recovery (Heppell et al. 2012). However, the scientific efforts for characterization and monitoring did not include most local fishers, thus the fishing community has perceived the closure negatively. Similarly, an important FSA site for groupers and snappers in Alacranes Reef, Mexico (Aguilar-Perera et al. 2008) was proposed as a $513 \mathrm{~km}^{2}$ NTZ in 2014. However, this initiative was not conducted in collaboration with local fishers or academics, causing the Regional Federation of Fishing Cooperatives in Yucatan to react with surprise and concern to the lack of consultation, and pressure from the fishing industry has since derailed the proposal.

In conclusion, this study illustrates that involving smallscale fishers as citizen scientists can play an important role in creating an enabling environment whereby fishers support full protection of FSAs in the Mexican MAR. We concur with McKinley et al. (2015) that citizen science contributes to natural resource science, management, environmental protection, and policymaking. In addition, whilst other factors are important (including underlying socio-economic conditions and awareness-raising efforts), the three-pronged approach of traditional ecological knowledge, western science, and participatory citizen science is vital for effective conservation outcomes.

\section{Acknowledgements}

This work was made possible by support from the Summit Foundation, the Oak Foundation, the Alianza WWF-Fundación Carlos Slim, the Walton Family Foundation, the David and Lucile Packard Foundation, the Marisla Foundation, LGL Ecological Research Associates, Inc., and the ESRI Conservation Program. The authors thank the six fishing cooperatives that operate in the Sian Ka'an and Banco Chinchorro Biosphere Reserves, the Comisión Nacional de Áreas Naturales Protegidas (CONANP), Comisión Nacional de Acuacultura y Pesca (CONAPESCA), the Kanan Kay Alliance, and the Quintana Roo Fish Spawning Aggregations Working Group for their support.

\section{Competing Interests}

The authors have no competing interests to declare.

\section{References}

ABALOBI. 2017. An ICT4Fisheries initiative and open, transdisciplinary and social learning endeavour. www. abalobi.info [Last accessed: 16 December 2017].

Aguilar-Perera, A. 1994. Preliminary observations of the spawning aggregation of Nassau grouper, Epinephelus striatus, at Mahahual, Quintana Roo, Mexico. Proceedings of the Gulf and Caribbean Fisheries Institute, 43: 112-122.

Aguilar-Perera, A. 2006. Disappearance of a Nassau grouper spawning aggregation off the southern Mexican Caribbean coast. Marine Ecology Progress Series, 327: 289-296. DOI: https://doi.org/10.3354/ meps 327289

Aguilar-Perera, A. 2013. An obituary for a traditional aggregation site of Nassau Grouper in the Mexican Caribbean. Proceedings of the Gulf and Caribbean Fisheries Institute, 66: 382-386.

Aguilar-Perera, A. and Aguilar-Dávila, W. 1996. A spawning aggregation of Nassau grouper Epinephelus striatus (Pisces: Serranidae) in the Mexican Caribbean. Environmental Biology of Fishes, 45(4): 351-361. DOI: https://doi.org/10.1007/BF00002527

Aguilar-Perera, A., Gonzalez-Salas, C., Tuz-Sulub, A., Villegas-Hernández, H. and López-Gómez, M. 2008. Identifying reef fish spawning aggregations in Alacranes Reef, off northern Yucatán Peninsula, using the fishermen traditional ecological knowledge. Proceedings of the Gulf and Caribbean Fisheries Institute, 43: 112-122.

Altbach, P.G. 2015. Evaluating and Rewarding Professors: Mexican Style. International Higher Education, 31: 12-14. DOI: https://doi.org/10.6017/ ihe.2003.31.7358 
Amigos de Sian Ka'an. 2003. Manejo Integrado de Recursos Costeros en Mahahual. Reporte Final. Periodo Octubre 2002-Septiembre 2003. Quintana Roo, Mexico. Amigos de Sian Ka'an. Appeldoorn, R.S. and Lindeman, K.C. 2003. A Caribbean-wide survey of no-take marine reserves: spatial coverage and attributes of effectiveness. Proceedings of the Gulf and Caribbean Fisheries Institute, 54: 780-781.

Arlettaz, R., Schaub, M., Fournier, J., Reichlin, T.S., Sierro, A., Watson, J.E.M. and Braunisch, V. 2010. From Publications to Public Actions: When Conservation Biologists Bridge the Gap between Research and Implementation. BioScience, 60(10): 835-842. DOI: https://doi.org/10.1525/bio.2010.60.10.10

ASK (Amigos de Sian Ka'an) and COBI (Comunidad y Biodiversidad). 2010. Protección de Agregaciones de Peces en Sian Ka'an. Informe técnico para PNUD. Quintana Roo, México. Amigos de Sian Ka'an and Comunidad y Biodiversidad.

Bobadilla, T.F.J. 2014. Diagnóstico socioeconómico de las comunidades pesqueras artesanales en Quintana Roo. Guaymas, México, Comunidad y Biodiversidad.

Bonney, R., Shirk, J.L., Phillips, T.B., Wiggins, A., Ballard, H.L., Miller-rushing, A.J. and Parrish, J.K. 2014. Next Steps for Citizen Science. Science, 343: 1436-1437. DOI: https://doi.org/10.1126/ science. 1251554

Burton, M.L., Brennan, K.J., Munoz, R.C. and Parker, R.O., Jr. 2005. Preliminary evidence of increased spawning aggregations of mutton snapper (Lutjanus analis) at Riley's Hump two years after establishment of the Tortugas South Ecological Reserve. Fishery Bulletin, 103: 404-410.

Butcher, G.S. and Niven, D.K. 2007. Combining Data from the Christmas Bird Count and the Breeding Bird Survey to Determine the Continental Status and Trends of North America Birds. National Audubon Society. New York, USA.

Castro-Pérez, J.M., Acosta González, G. and Arias-González, J.E. 2011. Characterizing spatial and temporal reef fisheries in Chinchorro Bank Biosphere Reserve, northern Mesoamerican Reef System. Hidrobiológica, 21(2): 197-209.

Cigliano, J.A., Meyer, R., Ballard, H.L., Freitag, A., Phillips, T.B. and Wasser, A. 2015. Making marine and coastal citizen science matter. Ocean and Coastal Management, 115: 77-87. DOI: https://doi.org/10.1016/j.ocecoaman.2015.06.012

Cinner, J.E. and Pollnac, R.B. 2004. Poverty, perceptions and planning: why socioeconomics matter in the management of Mexican reefs. Ocean and Coastal Management, 47(9-10): 479-493. DOI: https://doi. org/10.1016/j.ocecoaman.2004.09.002

Colin, P.L. 2012. Timing and location of aggregation and spawning in reef fishes. In: Sadovy de Mitcheson, Y. and Colin, P.L. (eds.), Reef Fish Spawning Aggregations: Biology, Research and Management, 117-158. Springer, Netherlands. DOI: https://doi.org/10.1007/978-94007-1980-4_5
CONANP. 2004. Programa de Manejo Parque Nacional Arrecifes de Xcalak. Mexico City, Mexico. Comisión Nacional de Áreas Naturales Protegidas.

Conrad, C.C. and Hilchey, K.G. 2011. A review of citizen science and community-based environmental monitoring: Issues and opportunities. Environmental Monitoring and Assessment, 176: 273-291. DOI: https://doi.org/10.1007/s10661-010-1582-5

Da Fonseca, G.A. 2003. Conservation science and NGOs. Conservation Biology, 17(2): 345-347. DOI: https:// doi.org/10.1046/j.1523-1739.2003.01721.x

Eklund, A.M., McClellan, D.B. and Harper, D.E. 2000. Black grouper aggregations in relation to protected areas within the Florida Keys National Marine Sanctuary. Bulletin of Marine Science, 66(3): 721-728.

Erisman, B., Heyman, W., Kobara, S., Ezer, T., Pittman, S., Aburto-Oropeza, O. and Nemeth, R.S. 2015. Fish spawning aggregations: where well-placed management actions can yield big benefits for fisheries and conservation. Fish and Fisheries. DOI: https://doi. org/10.1111/faf.12132

Franquesa-Rinos, A. and Loreto-Viruel, R.M. 2006. Reporte Final Sobre la Validación de Sitios de Agregaciones Reproductivas de Peces en el Norte de la Reserva de la Biosfera de Sian Ka'an, Quintana Roo, México. Cancún, Mexico. Amigos de Sian Ka'an.

Fulton, S., Caamal, J., Marcos, S. and Nalesso, E. 2016. Reporte técnico de los resultados de validación y monitoreo de los sitios de agregación reproductiva de pargos y meros en el centro y sur de Quintana Roo. Guaymas, Sonora, México. Comunidad y Biodiversidad.

Gibbons, P., Zammit, C., Youngentob, K., Possingham, H.P., Lindenmayer, D.B., Bekessy, S., Burgman, M., Colyvan, M., Considine, M., Felton, A., Hobbs, R.J., Hurley, K., McAlpine, C., McCarthy, M.A., Moore, J., Robinson, D., Salt, D. and Wintle, B. 2008. Some practical suggestions for improving engagement between researchers and policy-makers in natural resource management. Ecological Management and Restoration, 9(3): 182-186. DOI: https://doi.org/10.1111/j.14428903.2008.00416.x

Gleason, A.C., Kellison, G.T. and Reid, R.P. 2011. Geomorphic characterization of reef fish aggregation sites in the upper Florida Keys, USA, using single-beam acoustics. The Professional Geographer, 63(4): 443455. DOI: https://doi.org/10.1080/00330124.2011.5 85075

Goffredo, S., Piccinetti, C. and Zaccanti, F. 2004. Volunteers in marine conservation monitoring: a study of the distribution of seahorses carried out in collaboration with recreational scuba divers. Conservation Biology, 18(6): 1492-1503. DOI: https://doi.org/10.1111/j.15231739.2004.00015.x

Green, A.L., Fernandes, L., Almany, G., Abesamis, R., McLeod, E., Aliño, P.M., White, A.T., Salm, R., Tanzer, J. and Pressey, R.L. 2014. Designing marine reserves for fisheries management, biodiversity conservation, and climate change adaptation. Coastal Management, 42(2): 143-159. DOI: https://doi.org/10.1080/08920 753.2014 .877763 
Hamilton, R., de Mitcheson, Y.S. and Aguilar-Perera, A. 2012. The role of local ecological knowledge in the conservation and management of reef fish spawning aggregations. In: Sadovy de Mitcheson, Y. and Colin, P.L. (eds.), Reef Fish Spawning Aggregations: Biology, Research and Management, 331-369. Springer, Netherlands. DOI: https://doi.org/10.1007/978-94007-1980-4_10

Hamilton, R.J., Giningele, M., Aswani, S. and Ecochard, J.L. 2012. Fishing in the dark-local knowledge, night spearfishing and spawning aggregations in the Western Solomon Islands. Biological Conservation, 145(1): 246-257. DOI: https://doi.org/10.1016/j.biocon.2011.11.020

Hamilton, R.J., Potuku, T. and Montambault, J.R. 2011. Community-based conservation results in the recovery of reef fish spawning aggregations in the Coral Triangle. Biological Conservation, 144(6): 1850-1858. DOI: https://doi.org/10.1016/j.biocon.2011.03.024

Heppell, S.A., Semmens, B.X., Archer, S.K., PattengillSemmens, C.V., Bush, P.G., McCoy, C.M., Heppell, S.S. and Johnson, B.C. 2012. Documenting recovery of a spawning aggregation through size frequency analysis from underwater laser calipers measurements. Biological Conservation, 155: 119-127. DOI: https:// doi.org/10.1016/j.biocon.2012.06.002

Hernandez, A. and Kempton, W. 2003. Changes in fisheries management in Mexico: effects of increasing scientific input and public participation. Ocean \& Coastal Management, 46(6-7): 507-526. DOI: https:// doi.org/10.1016/S0964-5691(03)00032-2

Heyman, W.D. 2011. Elements for Building a Participatory, Ecosystem-Based Marine Reserve Network. The Professional Geographer, 63(4): 475-488. DOI: https://doi. org/10.1080/00330124.2011.585078

Heyman, W.D. and Kjerfve, B. 2008. Characterization of transient multi-species reef fish spawning aggregations at Gladden Spit, Belize. Bulletin of Marine Science, 83(3): 531-551.

Heyman, W.D., Olivares, M., Fulton, S., Bourillon, L., Caamal, J., Ribot, C. and Kobara, S. 2014. Prediction and verification of reef fish spawning aggregation sites in Quintana Roo Mexico. In: McConney, P., et al. (eds.), Enhancing Stewardship in Small-Scale Fisheries: Practices and Perspectives, 73-81. CERMES Technical Report No. 73.

Johannes, R.E. 1998. The case for data-less marine resource management: examples from tropical nearshore fin-fisheries. Trends in Ecology and Evolution, 13(6): 243-6. DOI: https://doi.org/10.1016/ S0169-5347(98)01384-6

June, A.W. 2013. Colleges begin to reward professors for doing work that actually matters to them. Chronicle of Higher Education. April 82013.

Knight, A.T., Cowling, R.M., Rouget, M., Balmford, A., Lombard, A.T. and Campbell, B.M. 2008. Knowing but not doing: selecting priority conservation areas and the research-implementation gap. Conservation
Biology, 22: 610-617. DOI: https://doi.org/10.1111/ j.1523-1739.2008.00914.x

Knispel, B., Allen, B., Cordes, J.M., Deneva, J.S., Anderson, D., Aulbert, C., Venkataraman, A., et al. 2010. Pulsar discovery by global volunteer computing. Science, 329(5997): 1305-1305. DOI: https://doi.org/10.1126/ science. 1195253

Kobara, S., Heyman, W.D., Pittman, S.J. and Nemeth, R.S. 2013. The biogeography of transient reef fish spawning aggregations in the Caribbean: a synthesis for future research and management. In: Hughes, R.N. and Smith, I.P. (eds.), Oceanography and Marine Biology: An Annual Review, 51: 281-326.

Locascio, J.V. and Burton, M.L. 2016. A passive acoustic survey of fish sound production at Riley's Hump within Tortugas South Ecological Reserve: implications regarding spawning and habitat use. Fishery Bulletin, 114(1): 103-116. DOI: https://doi.org/10.7755/FB.114.1.9

Mangin, T., Cisneros-Mata, M.Á., Bone, J., Costello, C., Gaines, S.D., McDonald, G., Rodriguez, L., Strauss, C.K. and Zapata, P. 2018. The cost of management delay: The case for reforming Mexican fisheries sooner rather than later. Marine Policy, 88: 1-10. DOI: https://doi. org/10.1016/j.marpol.2017.10.042

McClellan, C.M., Brereton, T., Dell'Amico, F., Johns, D.G., Cucknell, A.C., Patrick, S.C., Godley, B.J., et al. 2014. Understanding the distribution of marine megafauna in the English Channel region: identifying key habitats for conservation within the busiest seaway on earth. PloS one, 9(2): e89720. DOI: https://doi.org/10.1371/ journal.pone.0089720

McKinley, D.C., Miller-Rushing, A.J. and Ballard, H.L. 2015. Investing in citizen science can improve natural resource management and environmental protection. Issues in Ecology, 19: 1-27.

Medina-Quej, A., Herrera-Pavón, R., Poot-López, G., Sosa-Cordero, E., Bolio-Moguel, K. and Hadad, W. 2004. Estudio preliminar de la agregación del mero Epinephelus striatus en "El Blanquizal" en la costa sur de Quintana Roo, México. Proceedings of the Gulf and Caribbean Fisheries Institute, 55: 557-569.

Moreno, A., Bourillón, L., Flores, E. and Fulton, S. 2016. Fostering fisheries management efficiency through collaboration networks: the case of the Kanan Kay Alliance in the Mexican Caribbean. Bulletin of Marine Science. DOI: https://doi.org/10.5343/ bms.2015.1085

Pattengill-Semmens, C.V. and Semmens, B.X. 2003. Conservation and management applications of the REEF volunteer fish monitoring program. In: Melzian, B.D., et al. (eds.), Coastal Monitoring through Partnerships, 43-50. Springer, Dordrecht. DOI: https://doi. org/10.1007/978-94-017-0299-7_5

Pérez-Cervantes, E., Navarro-Espinosa, E., Estrada-Saldívar, N.A., Espinosa-Andrade, N., Melo-Merino, S.M., Rivas-Soto, M. and Álvarez-Filip, L. 2017. Estado de conservación de los arrecifes de coral de la Península de Yucatán. Puerto Morelos, Mexico. Greenpeace and UNAM. 
Roy, H.E., Pocock, M.J.O., Preston, C.D., Roy, D.B., Savage, J., Tweddle, J.C. and Robinson, L.D. 2012. Understanding citizen science and environmental monitoring: final report on behalf of UK Environmental Observation Framework. Natural History Museum, London, UK.

Russell, M.W., Sadovy de Mitcheson, Y., Erisman, B.E., Hamilton, R.J., Luckhurst, B.E. and Nemeth, R.S. 2014. Status Report-World's Fish Aggregations 2014. Science and Conservation of Fish Aggregations. California, USA. International Coral Reef Initiative.

Sadovy de Mitcheson, Y. 2016. Mainstreaming Fish Spawning Aggregations into Fishery Management Calls for a Precautionary Approach. BioScience. DOI: https://doi. org/10.1093/biosci/biw013

Sadovy de Mitcheson, Y. and Colin, P.L. 2012. Reef fish spawning aggregations: biology, research and management. Springer Science \& Business Media. Springer Netherlands. DOI: https://doi.org/10.1007/978-94007-1980-4

Sadovy de Mitcheson, Y., Cornish, A., Domeier, M., Colin, P.L., Russell, M. and Lindeman, K.C. 2008. A global baseline for spawning aggregations of reef fishes. Conservation Biology, 22(5): 1233-1244. DOI: https://doi. org/10.1111/j.1523-1739.2008.01020.x

Sadovy de Mitcheson, Y., Craig, M.T., Bertoncini, A.A., Carpenter, K.E., Cheung, W.W., Choat, J.H., Cornish, A.S., Fennessy, S.T., Ferreira, B.P., Heemstra, P.C. and Liu, M. 2012. Fishing groupers towards extinction: a global assessment of threats and extinction risks in a billion dollar fishery. Fish and Fisheries, 14(2): 119-136. DOI: https://doi.org/10.1111/j.1467-2979.2011.00455.x

Sadovy, Y. and Domeier, M. 2005. Are aggregation-fisheries sustainable? Reef fish fisheries as a case study. Coral Reefs, 24(2): 254-262. DOI: https://doi.org/10.1007/ s00338-005-0474-6

Sala, E., Ballesteros, E. and Starr, R.M. 2001. Rapid decline of Nassau grouper spawning aggregations in Belize: fishery management and conservation needs. Fisheries, 26(10): 23-30. DOI: https://doi.org/10.1577/15488446(2001)026<0023:RDONGS>2.0.CO;2

Secretaria de Gobernación. 1986. Decreto por el que declara como área que requiere la protección, mejoramiento, conservación y restauración de sus condiciones ambientales la superficie denominada Reserva de la Biósfera Sian Ka'an, ubicada en los Municipios de Cozumel y Felipe Carrillo Puerto, Q. Roo. Diario Oficial de la Federación. México.

Secretaria de Gobernación. 2007. Decreto por el que se expide la Ley General de Pesca y Acuacultura Sustentables. Diario Oficial de la Federación. México.

Secretaria de Gobernación. 2013. Acuerdo por el que se establece una red de zonas de refugio pesquero en aguas marinas de jurisdicción federal en las áreas de Banco Chichorro y Punta Herrero en el estado de Quintana Roo. Diario Oficial de la Federación. México.

Secretaria de Gobernación. 2014. Acuerdo por el que se da a conocer el Plan de Manejo Pesquero de Mero (Epinephelus morio) y especies asociadas en la Península de Yucatán. Diario Oficial de la Federación. México.

Secretaria de Gobernación. 2016. Acuerdo por el que se establece una red de dos zonas de refugio pesquero totales temporales en aguas marinas de jurisdicción federal ubicadas en la Bahía de la Ascensión en el Estado de Quintana Roo. Diario Oficial de la Federación. México.

Secretaría de Medio Ambiente y Recursos Naturales. 2014. Programa de Manejo Complejo Sian Ka'an: Reserva de la Biosfera Sian Ka'an, Área de Protección de Flora y Fauna Uaymil y Reserva de la Biosfera Arrecifes de Sian Ka'an. Mexico City, Mexico

SEMARNAP. 2000. Programa de Manejo de la Reserva de la Biosfera Banco Chinchorro. Secteraria de Medio Ambiente, Recursos Naturales y Pesca. Districto Federal, Mexico.

Sosa-Cordero, E., Medina-Quej, A., Herrera, R. and Aguilar-Dávila, W. 2002. Agregaciones reproductivas de peces en el sistema arrecifal mesoamericano. Consultoría Nacional-Mexico. Informe preparado para el consultor internacional, Research Planning Inc. y Proyecto SAM-Banco Mundial-Belice.

Theobald, E.J., Ettinger, A.K., Burgess, H.K., DeBey, L.B., Schmidt, N.R., Froehlich, H.E., Wagner, C., HilleRisLambers, J., Tewksbury, J., Harsch, M.A. and Parrish, J.K. 2015. Global change and local solutions: Tapping the unrealized potential of citizen science for biodiversity research. Biological Conservation, 181: 236-244. DOI: https://doi.org/10.1016/j.biocon.2014.10.021

Thornton, T.F. and Maciejewski-Scheer, A. 2012. Collaborative engagement of local and traditional knowledge and science in marine environments: a review. Ecology and Society, 17(3): 8. DOI: https://doi.org/10.5751/ ES-04714-170308

Velez, M., Adlerstein, S. and Wondolleck, J. 2014. Fishers' perceptions, facilitating factors and challenges of community-based no-take zones in the Sian Ka'an Biosphere Reserve, Quintana Roo, Mexico. Marine Policy, 45: 171-181. DOI: https://doi.org/10.1016/j. marpol.2013.12.003

Ward-Paige, C.A., Mora, C., Lotze, H.K., Pattengill-Semmens, C., McClenachan, L., Arias-Castro, E. and Myers, R.A. 2010. Large-scale absence of sharks on reefs in the greater-Caribbean: a footprint of human pressures. PloS One, 5(8): e11968. DOI: https://doi.org/10.1371/ journal.pone.0011968 
How to cite this article: Fulton, S., Caamal-Madrigal, J., Aguilar-Perera, A., Bourillón, L. and Heyman, W.D. 2018. Marine Conservation Outcomes are More Likely when Fishers Participate as Citizen Scientists: Case Studies from the Mexican Mesoamerican Reef. Citizen Science: Theory and Practice, 3(1): 7, pp.1-12, DOI: https://doi.org/10.5334/cstp.118

Submitted: 14 July 2017 Accepted: 25 March 2018

Published: 05 June 2018

Copyright: ( 2018 The Author(s). This is an open-access article distributed under the terms of the Creative Commons Attribution 4.0 International License (CC-BY 4.0), which permits unrestricted use, distribution, and reproduction in any medium, provided the original author and source are credited. See http://creativecommons.org/licenses/by/4.0/.

] $\mathrm{u}[\quad$ Citizen Science: Theory and Practice is a peer-reviewed open access journal published by Ubiquity Press. 